Abstracta Iranica

Revue bibliographique pour le domaine irano-aryen

Volume 32-33 | 2013

Comptes rendus des publications de 2009-2010

\title{
Gregory Kessel, Karl Pinggéra. A Bibliography of Syriac Ascetic and Mystical Literature
}

\section{Florence Jullien}

\section{(2) OpenEdition \\ 1 Journals}

Édition électronique

URL : http://journals.openedition.org/abstractairanica/40849

DOI : 10.4000/abstractairanica.40849

ISSN : 1961-960X

\section{Éditeur :}

CNRS (UMR 7528 Mondes iraniens et indiens), Éditions de l'IFRI

\section{Édition imprimée}

Date de publication : 1 décembre 2013

ISSN : 0240-8910

\section{Référence électronique}

Florence Jullien, «Gregory Kessel, Karl Pinggéra. A Bibliography of Syriac Ascetic and Mystical Literature », Abstracta Iranica [En ligne], Volume 32-33 | 2013, document 334, mis en ligne le 01 juillet 2016, consulté le 26 septembre 2020. URL : http://journals.openedition.org/abstractairanica/40849 DOI : https://doi.org/10.4000/abstractairanica.40849

Ce document a été généré automatiquement le 26 septembre 2020.

Tous droits réservés 


\title{
Gregory Kessel, Karl Pinggéra. A Bibliography of Syriac Ascetic and Mystical Literature
}

\author{
Florence Jullien
}

\section{RÉFÉRENCE}

Gregory Kessel, Karl Pinggéra. A Bibliography of Syriac Ascetic and Mystical Literature.

Louvain, Peeters, 2009, xx-224 p. (Eastern Christian Studies, 11)

1 Cet ouvrage est un outil synthétique et exhaustif recensant les auteurs mystiques en milieu ascétique syriaque, couvrant selon un ordre chronologique les origines et les développements du mouvement mystique jusqu'à l'époque moderne (1714). Sous chaque entrée, sont signalées les éditions de référence concernant les auteurs et les textes, mais aussi les traductions éventuelles disponibles ainsi que la littérature secondaire. Les AA. ont eu soin d'ajouter d'autres rubriques de thématiques connexes comme les anthologies monastiques, le proto-monachisme, les courants pneumatiques (messalianisme par exemple).

\section{AUTEURS}

FLORENCE JULLIEN

EPHE, Paris 